\title{
ПРАК СА
}

UDC 351.778 .534

\section{ПИТАЊЕ НАДЛЕЖНОСТИ ЗА ДОДЕЛУ СТАНА НА ПРИВРЕМЕНО КОРИШТЕЊЕ (слободна воља директора као неприкосновена)*}

\section{- Поводом једне судске одлуке -}

Опште је познат и широко прихваћен у нормативним актима предузећа и других давалаца стана на коришћење институт доделе стана на привремено коришћење запосленом који поседује коначну одлуку о додели стана.

Установљење овог института проистекло је из животних разлога. Намера је да се стан који је предмет расподеле „заштити” од могућих злоупотреба, као што је незаконито усељење трећег лица, с једне стране, и заштита права запосленог, који је на нивоу послодавца „издржао конкуренцију”. Редак је случај да се на коначној одлуци заврши поступак доделе стана без тужбе суду. Такође је редак случај да се судски поступак брзо оконча.

Одлуку (решење) о додели стана на привремено коришћење доноси директор.

Питање које се логично намеће јесте да ли запослени коме је стан додељен на привремено коришћење ужива судску заштиту овог свог привременог права.

Судећи по судској пракси, која је непосредан повод за овај коментар, оваква заштита не постоји. Утолико и сам институт доделе стана на привремено коришћење губи сваки смисао.

У конкретном случају тужилац поседује коначну одлуку о додели стана на коришћење. У стану се налази други запослени, такође учесник конкурca, али по основу који је отпао. У посед стана ушао је на основу раније одлуке стамбене комисије послодавца, која је, као и цео конкурс поништена. Поседује уговор о закупу стана који се заснива на поништеној одлуци.

Тужилац, међутим, поседује коначну одлуку о додели стана по актуелном, једино важећем конкурсу. Директор даваоца стана на коришћење прво

* Рад примљен: 07. II 2002. 
доноси решење о додели стана на привремено коришћење тужиоцу, да би, затим, то своје решење поништио.

Тужилац покреће судски поступак ради поништаја решења директора којим је поништено решење о додели стана на коришћење. Истом тужбом захтева да се обавеже давалац стана на коришћење на привремену предају поседа предметног стана до правоснажности одлуке о додели стана на коришћење.

Првостепени суд тужбени захтев делимично усваја у делу где поништава незаконито решење директора о поништају решења којим је стан додељен тужиоцу на привремено коришћење, а одбија у делу захтева за предају поседа стана.

У образложењу пресуде утврђена је незаконитост решења директора, које је поништено, ништавост основа за коришћење стана запосленог који га користи, затим је утврђено да исти више нема право да стан користи, да би коначни закључак био: предаја поседа тужиоцу могућа је само на привремено коришћење (то уопште и није спорно), а што СПАДА У НАДЛЕЖНОСТ ДИРЕКТОРА, А НЕ У НАДЛЕЖНОСТ СУДА. Даље у пресуди стоји да то значи да би тужени, након правоснажности пресуде, био у обавези да тражи предају поседа, а не тужилац (пресуда Општинског суда у Новом Саду, посл. бр. П574/2000. од 17. 05. 2000).

Поступајући по жалби тужиоца, другостепени суд у свему прихвата разлоге првостепеног суда и жалбу одбија поново утврђујући ДА ЈЕ ДОДЕЛА СТАНА НА ПРИВРЕМЕНО КОРИШЋЕЊЕ У ИСКЉУЧИВОЈ НАДЛЕЖНОСТИ ДИРЕКТОРА (пресуда Окружног суда у Новом Саду, посл. бр. Гж 2363/2000. од 17. 08. 2000).

На крају, поступајући по ревизији тужиоца, Врховни суд Србије својом пресудом посл. бр. Рев. 5799/00. од 04. 10. 2001. год. ревизију одбија уз исто образложење као и нижестепени судови да је додела стана на привремено коришћење у искључивој надлежности директора.

Није спорно да је додела стана на привремено коришћење у искључивој надлежности директора, али је спорно што суд у случају када директор не извршава коначно и правоснажно решење о додели стана на привремено коришћење уопште не pearyje.

Решење директора о додели стана на привремено коришћење не представља извршни наслов у.смислу ЗИП. Дакле, тужилац нема могућности да судским путем захтева извршење решења.

У спору за поништај незаконитог решења директора успева, али само „pro forma”. Практично је у стану лице без правног основа, а тужилац са правним основом чека правоснажност одлуке о додели стана.

Следећи логику изложене судске праксе, не постоји уопште судска заштита запосленог коме је стан додељен коначном одлуком послодавца, јер нема могућност да судским путем исходује привремену предају поседа стана који му је додељен.

Мора сачекати правоснажност одлуке о додели стана (али тада предаја поседа више није привремена него трајна). Да подсетим, овде је реч о додели стана на привремено коришћење пре правоснажности одлуке. 
Каква је уопште сврха постојања института доделе стана на привремено коришћење уколико се фаворизује лице које стан користи без основа у односу на легитимног имаоца коначне одлуке о додели стана?

Да ли заиста има смисла препустити остваривање тако важног права (привременост често подразумева и више година) волунтаризму директора без могућности судске заштите?

Шта уопште значи да је додела стана на привремено коришћење у надлежности директора а не суда? Од суда се ни не очекује да стан додели (већ је додељен) него управо да тог истог надлежног директора обавеже да правоснажно решење о додели стана на привремено коришћење изврши.

Нажалост, у конкретном случају, тужилац, иако делимично успео у спору, чека на правоснажност одлуке у подстанарском стану док се у стану за који има правоснажно решење о додели на привремено коришћење налази лице без правног основа.

Тако је суд одлучио на три инстанце, па остаје само овај коментар за размишљање.

Загорка Мунижаба адвокат у Новом Саду 